\title{
Green Manufacturing: Solution for Indian Climate Change Commitment and Make in India Aspirations
}

\author{
Nikhil Sudhir Kothawade \\ M.Tech Manufacturing (2013-2015), VIT University, Vellore, Tamilnadu
}

\begin{abstract}
The industry centric economic growth aspired by India with its ambitious MAKE IN INDIA initiative is progressing rapidly. Year 2015 witnessed major global initiatives to limit global warming. To achieve Sustainable Development Goals and commitments of Paris pledge to limit GHG's production is well reflected by India's INDC program and various environmentally conscious development initiatives. With promising INDC and initiatives like Zero Effect-Zero Defect, Perform-Achieve-Trade and others a path for green manufacturing has been set by government. This paper highlights necessity of green manufacturing to achieve India's dual challenges by organizing climate competitive manufacturing development. Green manufacturing being relatively new concept; its various key areas of applications and critical success factors for application are also discussed. Present paper argues the case of speeding up of green approach in manufacturing industry to enhance climate competitiveness of Indian product.
\end{abstract}

Keywords: Green Manufacturing, India’s INDC, Make In India, Green practices, GHG Emissions

\section{Introduction}

Stable government in India post 2014 general elections has brought many new developmental initiatives. Indian government riding high for making India global manufacturing hub with its ambitious program "Make In India". Prime Minister Narendra Modi announced "Make In India" from ramparts of historic red fort on $15^{\text {th }}$ august 2014. Make In India is not only an attempt to achieve goals set in National manufacturing Policy (NMP), 2011 which argues for enhancing share of manufacturing in GDP to 25 percent by 2022 but it also sought climate competitive manufacturing sector growth which is in tandem with current global climate change responsibilities [1],[2].

World at large is becoming climate conscious each day. With COP 21 Paris deal world at large shown solidarity to fight climate change and decided to endure a sustainable development. The Paris Agreement's central aim is to strengthen the global response to the threat of climate change by keeping a global temperature rise this century well below 2 degrees Celsius above pre-industrial levels as suggested by IPCC AR5 [3] and to pursue efforts to limit the temperature increase even further to 1.5 degrees Celsius. Additionally, the agreement aims to strengthen the ability of countries to deal with the impacts of climate change [4].Sustainable development goals launched in September 2015 in succession of Millennium development goals are in concurrence with world voice over climate change. Out of 17 SDG's some argues specifically for green growth and promoting efforts to reduce ill impacts of climate change. Goal 9 argues for building resilient infrastructure, promote inclusive and sustainable industrialization and foster innovation. Sub goal 9.4 argues to upgrade and retrofit industries to make them sustainable, with increased resource-use efficiency and greater adoption of clean and environmentally sound technologies and industrial processes. Goal 13 specifically argues for taking urgent action to combat climate change and its impacts well assessed by IPCC reports [5].

The cumulative accumulation of greenhouse gases (GHG's) historically since industrial revolution has resulted in global warming. India has been an active and constructive participant in the search for solutions and committed to engaging actively in multilateral negotiations under the UNFCCC in a positive, creative and forward-looking manner. It seeks to establish an effective, cooperative and equitable global architecture based on climate justice and Common but Differentiated Responsibilities and Respective Capabilities (CBDR-RC). India believes that development and environment are not adversaries but can go hand in hand, if environmental sensibilities can be imbibed. Equitable, inclusive and sustainable development would be the key to a new model of growth that India is committed to pursue. Keeping in view its development agenda and climate change responsibilities India has announced its Intended Nationally Determined Contribution (INDC) for period 2021 to 2030 which argues for climate friendly development in future [6].

Citing this dual commitment of development with "Make in India" and contributing to global climate change cause with its ambitious INDC's; India is looking for greener technologies which can ensure sustainable developments and achieve green growth. Green manufacturing is one such solution which India can significantly adopt in its manufacturing development commitments and can enhance climate competitiveness of Indian products. Green manufacturing (GM) is a term used to describe manufacturing practices that do not harm the environment during any part of the manufacturing process [7]. Green manufacturing holds potential to address both production and environmental challenges singularly [8][9].

This paper is an attempt to not only to highlight India's manufacturing ambitions with green growth strategies and climate commitments but also discusses various perspectives of green manufacturing which carries 


\section{International Journal of Science and Research (IJSR) \\ ISSN (Online): 2319-7064 \\ Index Copernicus Value (2015): 78.96 | Impact Factor (2015): 6.391}

potential[10] to be implemented widely. Paper also discusses green manufacturing framework to be applied in Industry. By studying literature this paper tries to identify some green manufacturing methods to be used in industry.

\section{Manufacturing Outlook}

\subsection{Indian manufacturing industry and GHG emissions}

Globally Manufacturing sector accounts for some 35 per cent of global electricity use, 20 per cent of $\mathrm{CO} 2$ emissions, and a one fourth of primary resource extraction. It has a major impact on the environment and must be factored into the climate change equation. At the same time, the sector's economic importance cannot be ignored which currently accounts for 23 per cent of worldwide employment [11].

The Indian manufacturing sector is a classic example of an industry having great potential, but suffering from political ineffectiveness, entrepreneurial myopia and sheer ignorance of what it takes to succeed. Over last 20 years, Indian manufacturing registered significantly slow growth. Between

1993 to 2013 India's share in global GDP increased from 1.2 per cent to 2.5 per cent [12]. But country has marked its presence as growing economy and an emerging manufacturing destination with strong technical and engineering capabilities backed by top-notch scientific and technical institutes. Data in figure 1 is India's GDP from manufacturing released by Central statistical organization (CSO) of India and analyzed by tradingeconomics.com shown consistent growth of manufacturing and similar trend is forecasted which backs the argument [13].

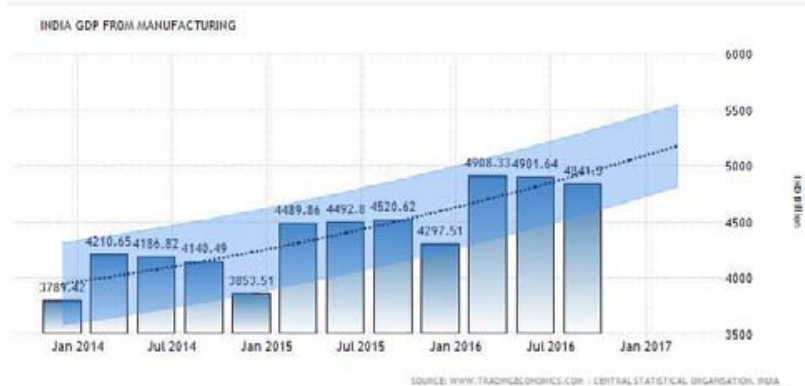

Figure 1: India GDP from manufacturing (IND Billion)

New manufacturing Policy (NMP) argues for increasing contribution of manufacturing sector to 25 percent in India's GDP by 2022. Making manufacturing sector as engine of India's growth, rather than services sector (which has been the prime mover of GDP in recent years) means a significant acceleration in the amount of energy required to fuel India's development.

Universal round the clock electricity supply and an expanded share of manufacturing in gross domestic product (GDP) under "Make In India" campaign are defined as two pillars of development. This vision for India would have profound implications for its energy system [14]. Almost three-quarters of Indian energy demand is met by fossil fuels, a share that has increased since 2000. Figure 2 shows pattern of energy Consumption. [15]. Significant growth of $11 \%$ in use of coal is noted between year 2000 and 2013.

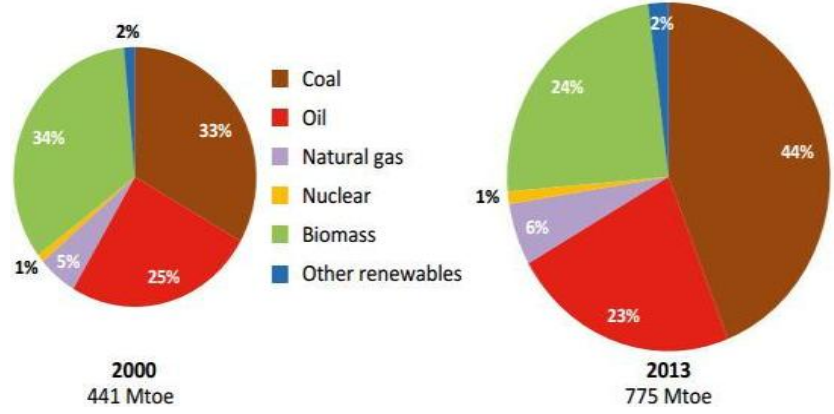

Figure 2: Primary energy demand in India by fuel

India though shifting to renewable energy rapidly, GHG emissions are equally increase and can be observed from graph shown in figure 3 [16]. Various models like TERIPoznan, McKinsey, TERI-MoEF, IRADe-AA, NCAERCGE are employed to forecast GHG emissions. Both figures 2 and 3 well anticipate growth in fossil fuel use and thereby growth in GHG emissions. So the onus lies on shoulders of manufacturing sector which can make changes and be more climates competitive by shifting to green manufacturing practices.

Total GHG emissions, billion tons $\mathrm{CO}_{2} \mathrm{e}$

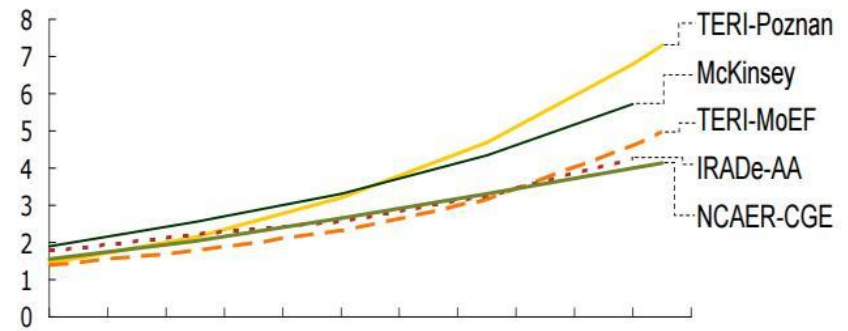

201020122014201620182020202220242026202820302032

Year

Figure 3: Aggregate GHG emission projections for India by5 different models

\subsection{Make in India}

With the objective of making India a global hub of manufacturing, design and innovation, the Make in India initiative, which is based on four pillars as new processes, new infrastructure, new sectors and new mindset, has been taken by the government. An interactive portal http://makeinindia.com has been created which gives information about the initiative and all the relevant thrust sectors where Make In India can serve its purpose has been mentioned.

Increase in manufacturing sector growth to $12-14 \%$ per annual over the medium term and increasing share of manufacturing in country's GDP from $16 \%$ to $25 \%$ by 2022

[1], enhancing global competitiveness of Indian Manufacturing and ensuring sustainability of growth, particularly with regard to environment is envisioned by Make In India [2]. This vision and NMP speaks itself for unprecedented growth of manufacturing sector in future. Mining, Oil and Gas, Automobile and its components, Thermal Power, defence manufacturing..etc. are some of the thrust sectors which are emission intensive too. Incentives are also provided for adopting green practices in

\section{Volume 6 Issue 1, January 2017




\section{International Journal of Science and Research (IJSR) \\ ISSN (Online): 2319-7064}

Index Copernicus Value (2015): 78.96 | Impact Factor (2015): 6.391

this initiative. Exclusive emphasis on sustainability and climate competitiveness in Make in India vision creates new ground for Green approach in manufacturing sector.

\section{India's Climate Commitments}

\subsection{GHG emissions and discussion}

Figure 2 and 3 projects increase in GHG emission. Figure 1 also at the same time highlights growth prospects of Indian
Manufacturing sector. Figure 4 breakdowns of GHG emissions within the energy sector. According to Figure 4[17] share of GHG emission from Manufacturing industries and construction was $20.26 \%$ in 1994 and in subsequent years it reduced infinitesimally to $19.91 \%$ in 2010. It can be understood from the above discussion that Indian manufacturing sector needs to improve its emission reduction potential.

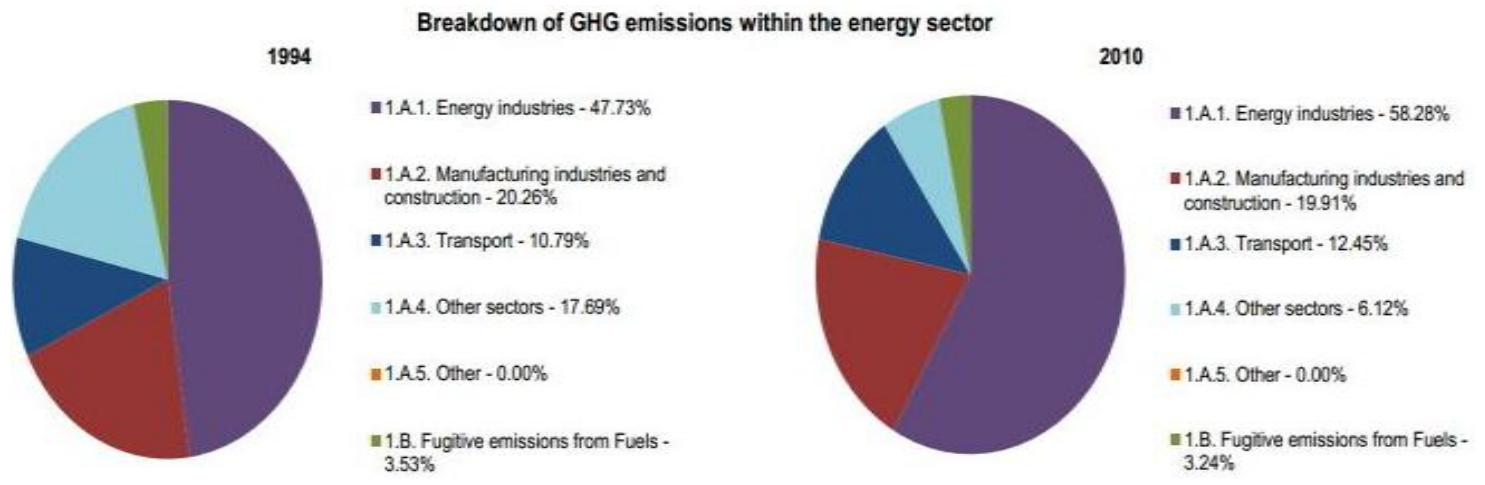

Figure 4: Breakdown of GHG emissions within energy sector

Growing energy demands are met with conventional ways of energy production leading to increase in emission from energy industries significantly. Figure 5 [18] gives information about greenhouse gas inventory data. Share of mineral productions in GHG emission is increased more than double from 1994 to 2010 owing to India's energy demands.

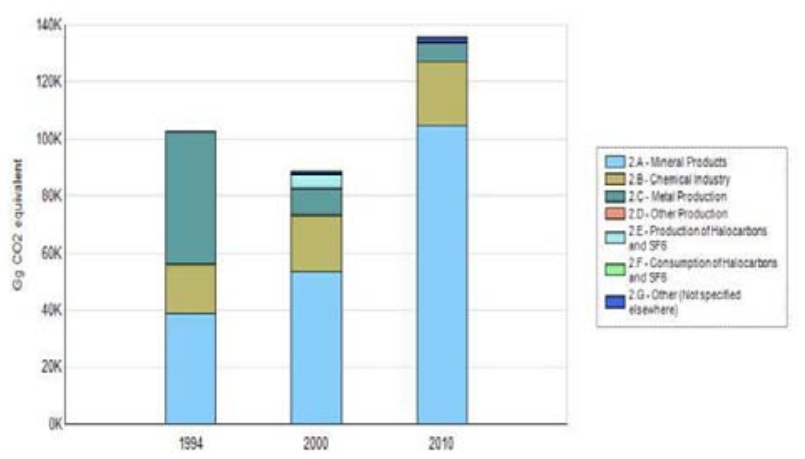

Figure 5: Greenhouse gas inventory data for industrial processes

\subsection{India's INDC: Push to green manufacturing}

India believes that international partnership must be at the center of efforts to combat climate change and development. However it also recognizes its development needs and philosophy of CBDR-RC. Idea of Vasudhaiva Kutumbakam (All World one family) is well embraced in its mitigation strategies in INDC document to combat climate change.

India's ambitious INDC goals proved that its development program is in line with global climate commitments. Reducing the emission intensity of its GDP by 33 to 35 percent by 2030 from 2005 level, building capacity to achieve green growth and creation of carbon sink of 2.5 to 3 billion tons of $\mathrm{CO} 2$ equivalent through additional forest cover by 2030 exclusively argues in INDC's for combating climate change and achieving development in tandem [6].

Another goal of INDC is to build capacities, create domestic framework and international architecture for quick diffusion of cutting edge climate technology and for joint collaborative R \& D for such future technologies. Policies of Make In India discussed on Make In India portal [2] and INDC goals indeed find a concurrence in its development approach. This approach can also be referred as green growth approach.

\subsection{Indian strategy to develop climate resilient industry}

\subsubsection{Green Growth approach}

Various perspectives of green growth can be observed from abundant literature on subject. It has been argued by green growth proponents that environmental stewardship is no impediment to economic prosperity and may spur growth [19]. Green growth advocates do look to environmental management as just another economic sector alongside conventional activity but they argue that the economic changes required to combat problems like climate change are not marginal, as most traditional models suggest, but transformative and system-wide. The creation of a green economy will therefore affect not just a few sectors but the product mix and production processes of virtually the whole economy [20-21]. Sam Fankhuser. Et.al interpreted green growth as an economy-wide transformation, which may include structural, policy level changes [10] rather than the expansion of the environmental goods and services sector. OECD sees to Green growth [22] as fostering economic growth and development while ensuring that natural assets continue to provide resources and environmental services on which our well-being depends.

\section{Volume 6 Issue 1, January 2017




\section{International Journal of Science and Research (IJSR) \\ ISSN (Online): 2319-7064}

Index Copernicus Value (2015): 78.96 | Impact Factor (2015): 6.391

Green growth is not a phenomenon having "one-size-fitsall" approach. From policy, institutional, structural, behavioural changes, financing new market and innovations opportunities could help to deliver goal of green growth. Report [23] also argues for sustainable manufacturing and green growth. Supporting industry by providing information and knowledge on green practices, providing skill sets in concurrence with green technology, creation of new business models to enhance focus of local production and innovation systems to achieve sustainability in manufacturing systems.

Comprehending various literature cited above it can be understood that green growth for manufacturing sector is nothing but structural and innovation changes in industry which ultimately pushes for green manufacturing.

\subsubsection{Indian mitigation and adaptation strategy for climate change}

The IPCC report has reiterated that climate change is real and its impact is being felt across countries of the world. Mitigation action is immediately required to limiting atmospheric concentration of greenhouse gases. It implies shifting away from current energy system to fundamentally different decarbonized energy system. India, owing to its large agricultural sector, vast population, rich biodiversity, long coastline, and high poverty levels is expected to be one of the most vulnerable countries for climate change. [3]

India's environmental stewardship is reflected in its climate conscious growth approach. It involves various strategies and initiatives which can bring efficiency and climate competitiveness in Manufacturing Processes. Its multipronged approach to fight climate change ranges from shifting to renewable energy from conventional energy resources, Imbibing green manufacturing practices and also seeking behavioural changes for climate consciousness in all sectors and institutions of Indian economy.

Creation of clean and efficient energy system which involves shifting to renewable energy resources, clean coal policies is significant in India's mitigation strategy. National Smart Grid

Mission to bring efficiency in power supply and facilitate reduction in losses and outage. Green energy corridor projects are also rolled out to ensure evacuation of renewable energy. National mission for enhanced energy efficiency (NMEEE) aims to strengthen market for energy efficiency with regulatory and policy regime. [6]

Apart from Make In India, National Industrial corridors, streamlining environment and forest approvals initiatives have been taken to reduce energy consumption in industry. Apart from numerous initiatives following two are manufacturing industries centric.

a) Perform Achieve and Trade (PAT) : It is market based energy efficiency trading mechanism. With mandated decrease in specific energy consumption under PAT program will help firms to get Energy Saving certificate which can be traded. This initiative is launched for eight energy intensive sectors accounting for one third of total energy consumption in country. b) Zero Effect, Zero Defect (ZED): The Make in India campaign with ZED is a policy initiative to rate Medium \& Small Industries on quality control and certification for energy efficiency, enhanced resources efficiency, pollution control, use of renewable energy, waste management etc. using ZED Maturity Assessment Model. This initiative is an important step in the direction of encouraging companies to focus on product quality while reducing waste of natural resources.

c) The Capacity Building for Industrial Pollution Management (CBIPM): The project will help the Government of India (GOI) to build capacity at the state and central level, and develop a framework to address these issues in a comprehensive and systemic manner under an area-wide management approach. The proposed project is aligned with the endeavour of the GOI to establish a National Program for Rehabilitation of Polluted Sites (NPRPS) as a framework for scaling up the clean-up and rehabilitation of polluted sites and facilitate the reduction of environmental and health risks associated with legacy polluted sites.

\section{Green Manufacturing}

\subsection{What is Green Manufacturing?}

Green manufacturing (GM) is a term used to describe manufacturing practices that do not harm the environment during any part of the manufacturing process [7]. GM stresses on reducing parts, rationalizing materials, and reusing components, to help make products more efficient to build.

It emphasizes the use of processes that do not pollute the environment or harm consumers, employees, or other members of the community. Green manufacturing addresses a number of manufacturing matters, including 4R's (Reduce,

Reuse, Recycle and Remanufacturing), conservation, waste management, water supply, environmental protection, regulatory compliance, pollution control, and a variety of related issue [8]

Green manufacturing involves transformation of industrial operations in three ways: (1) using Green energy, (2) developing and selling Green products and (3) employing Green processes in business operations [25].

\subsection{Significance}

Sustainability challenge: Increased industrialisation has led to growth in waste and e-waste generation, pollution due to ineffective waste disposal, GHG emission, and improper disposal of industrial effluents due to meet the growing demand of population. Transforming to green manufacturing by shifting towards green energy, products and processes can help to meet this sustainability challenge.

According to analysis [12] done as shown in figure 6 that

India's top requirements towards "Make In India" are in concurrence with the key facilitators of green 


\section{International Journal of Science and Research (IJSR) \\ ISSN (Online): 2319-7064 \\ Index Copernicus Value (2015): 78.96 | Impact Factor (2015): 6.391}

manufacturing mentioned in another analysis [24].

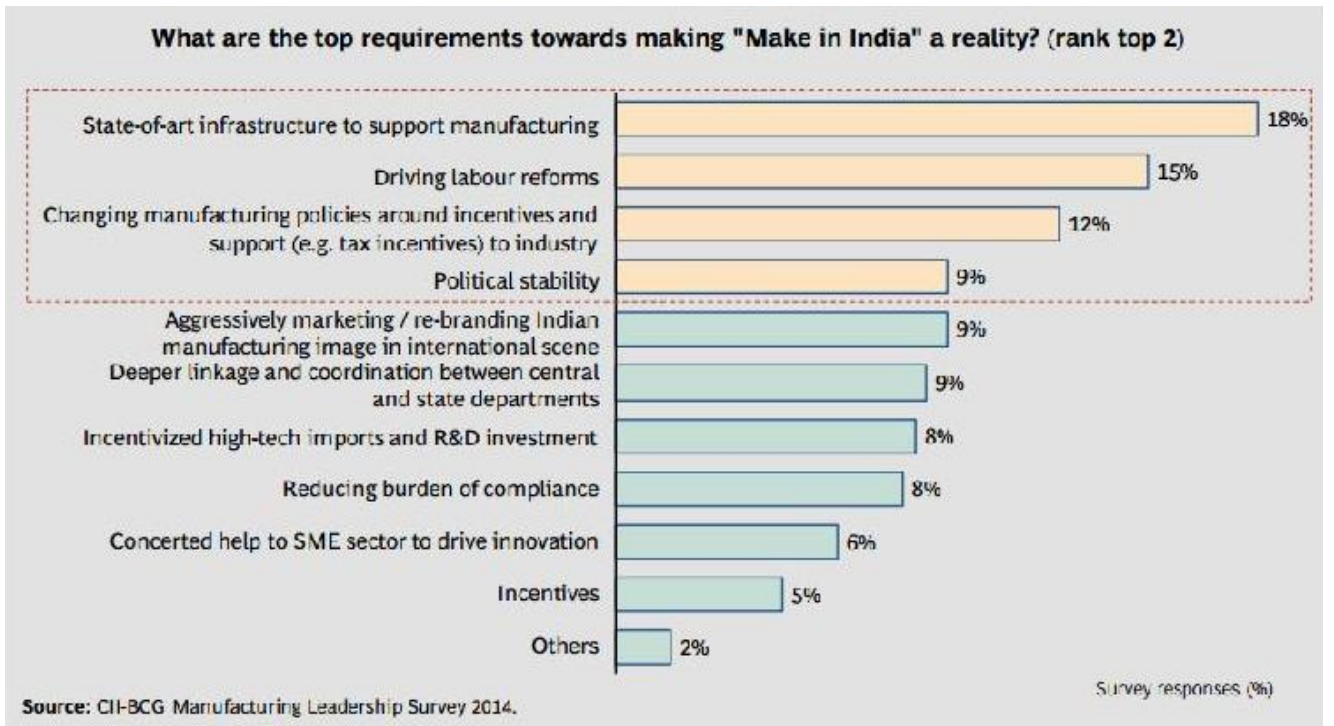

Figure 6: Requirements of turning Make In India a reality

Further forecasts by various organizations which is summed up in figure 7 appeared in [12] highlights aspirational

growth of manufacturing sector.

\begin{tabular}{|c|c|c|c|c|}
\hline \multicolumn{5}{|c|}{ Comparison of manufacturing GDP ${ }^{1}\left(2013-E^{2030}\right)^{2}$} \\
\hline \multicolumn{2}{|c|}{2013} & & \multicolumn{2}{|c|}{ Estimate 2030} \\
\hline Country & USD trillion & & Country & USD trillion \\
\hline China & 2.94 & & China & 7.00 \\
\hline United States & 2.17 & & United States & 3.22 \\
\hline Japan & 0.89 & $11 \%^{2}$ & India & 1.42 \\
\hline Germany & 0.79 & $10 \%^{3}$ & India & 1.22 \\
\hline Korea, Rep. & 0.41 & & Japan & 1.13 \\
\hline Italy & 0.32 & & Germany & 0.98 \\
\hline Brazil & 0.29 & $6.5 \%{ }^{4}$ & India & 0.70 \\
\hline India & 0.24 & $5 \% 5$ & India & 0.55 \\
\hline Mexico & 0.22 & & Indonesia & 0.51 \\
\hline Indonesia & 0.21 & & Brazil & 0.45 \\
\hline $\begin{array}{l}\text { e: EIU, Euromonit } \\
\text { IManufacturing G } \\
\text { d on high anbition } \\
\text { d on government a } \\
\text { don ElU estimatio } \\
\text { don least ambitio }\end{array}$ & $\begin{array}{l}\text { lysis. } \\
\text { cost, constant prices (2013). } \\
\text { sinal NMP. } \\
\text { idership growth ambition. }\end{array}$ & & & $\begin{array}{l}\text { CAGR } \\
\text { ound Annual Growth Rate }\end{array}$ \\
\hline
\end{tabular}

Figure 7: Aspirational growth of Indian manufacturing sector

\subsection{Forces driving green manufacturing}

Much research has been done on finding out critical success factors (CSF) driving Green Manufacturing Practices. It has been also argued by that industry focus on reducing, energy consumption, waste generation, emission reduction, reducing hazardous substances, or getting ISO 14001 as factors driving green manufacturing. Working conditions are also analyzed as Green manufacturing driving factors by some researchers [26] and concluded that temperature at workplace plays critical role in productivity and labour supply. Some research stresses on various CSFs of green manufacturing viz. meeting customer's needs, environmental trade-offs, reuse, recycle life cycle approach, green design, disposal etc. Devashish Pujari [27] includes environmental benchmarking and measurement, effective groundwork, cross-functional coordination, environmental database, supplier involvement, environmental policy/ legitimation as critical success factors. Three other factors emerging with relatively low variance were top management support and involvement, product experimentation, and environmental coordinator. All the discussion on analysing driving factor for green manufacturing suggest that these factors range from organizational setup, behavioural change to technical changes in products, processes and energy to ensure sustainability. All these factors are termed as Critical Success factors driving green manufacturing environment in 


\section{International Journal of Science and Research (IJSR) \\ ISSN (Online): 2319-7064 \\ Index Copernicus Value (2015): 78.96 | Impact Factor (2015): 6.391}

manufacturing industry.

A number of companies have started adopting Green initiatives as an integral part of their operations. By analysing above literary resources and various case studies[7][24] following factors are observed in common which led to green manufacturing These initiatives are driven by factors and can be termed as common critical success factors:

- Growing energy and input costs due to scarcity of resources

- Consumer interest in green product

- Increasing regulatory pressures due to new and stricter environmental and waste management laws

- Technological innovation which open up new attractive business opportunities and growing it further

- The need to enhance competitive differentiation, particularly for first movers or those who are able to break the compromise between short-term higher costs and numerous benefits (example: brand premium, new customer segments)

- Organisational commitments and top management vision

\subsection{Information Communication and Technology (ICT): An enabler for green manufacturing}

Role of Information, Communication and Technology (ICT) in key resource intensive manufacturing sector[24] including transportation sector is significant. Its prospects are discussed below.

\subsubsection{Transportation sector}

Electric vehicles (EV), fuel cells and bio-diesel are some examples of this category. Battery operated electric vehicle,
Hybrid electric vehicle, Fuel cell vehicle are some types of green transportation. Adoption of ICT in transportation has been driven by many factors, such as reducing price, reducing size and weight of equipment, emergence of smart-phones and cloud services for data analysis has helped to build Wireless Fleet management System which optimises end to end routes for transporting vehicle. Location based fleet management is possible with GPS tools which helps driver to navigate to their destinations in efficient way.

\subsubsection{Manufacturing sector}

Automation of industrial processes: Involves modernizing plants which will be controlled by ICT devices. Higher level of control of equipment will help reduce and optimize energy use foe a given manufacturing process.

Optimization of variable speed motor system: It can overcome limitation posed by inefficient traditional motor systems that work at constant rate. 3D Manufacturing/ Printing: Object is created by laying down successive layers of raw materials through an additive manufacturing process.

Traditional industries like iron and steel, cement, refining, chemicals..etc can also switch to green methods of production. Figure 8, an analysis [24] indicates the technologies and the potential savings they could create by switching to green production. Multiple technologies are emerging in this industry and promising future for green manufacturing can be anticipated. Almost 180 green technologies were analysed and possible saving potential is calculated industry wise. Building and Iron and steel industry hold maximum potential to curb energy losses. Cement industry also by redesigning of process can realize significant energy saving potential.

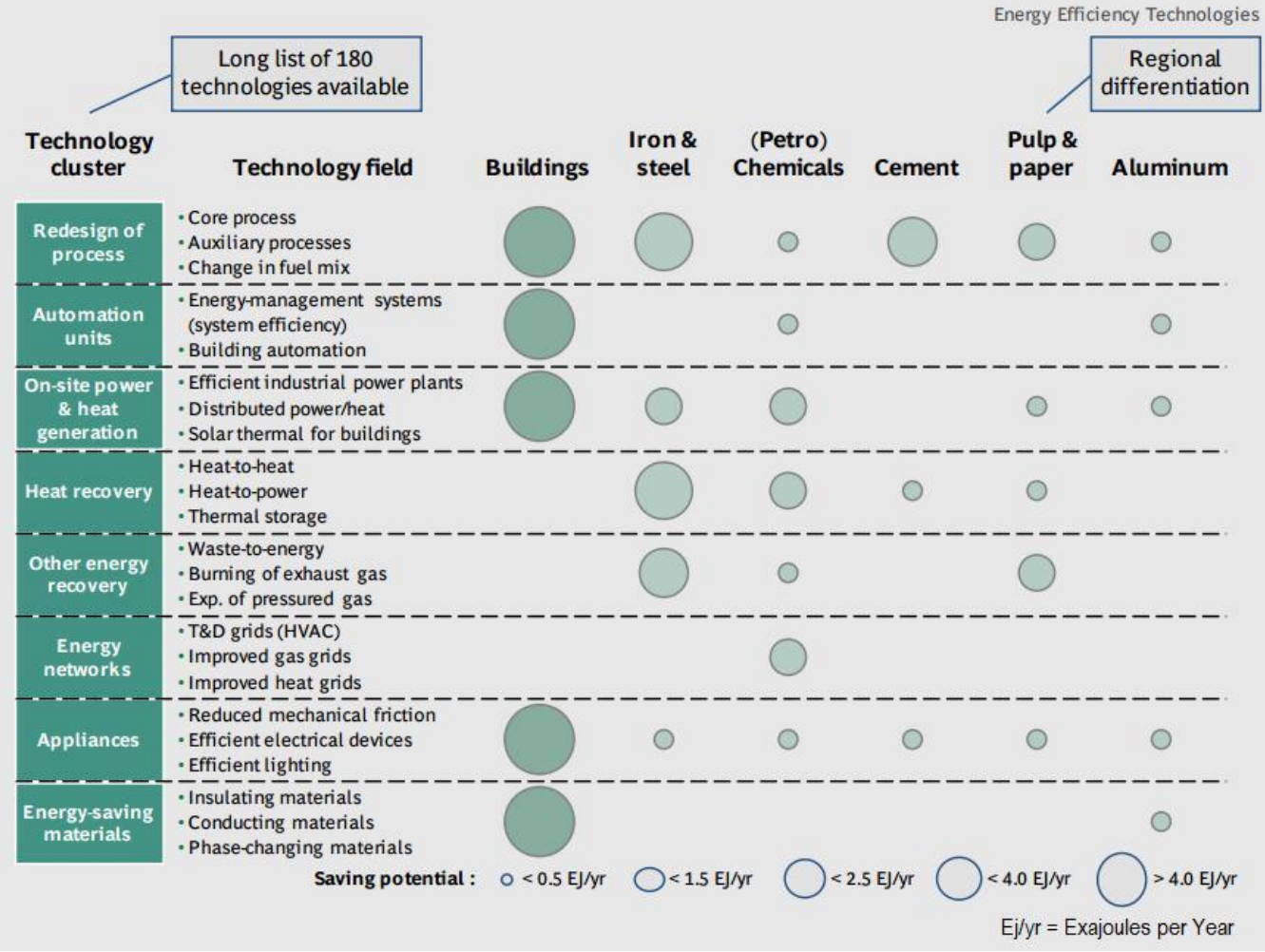

Figure 8: Energy saving potential by technology clusterand application area

Volume 6 Issue 1, January 2017

www.ijsr.net

Licensed Under Creative Commons Attribution CC BY 


\section{International Journal of Science and Research (IJSR) \\ ISSN (Online): 2319-7064}

Index Copernicus Value (2015): 78.96 | Impact Factor (2015): 6.391

\subsection{Framework for adoption of green manufacturing}

Successful implementation of Green manufacturing requires going beyond small standalone initiatives, and adopting an integrated three-step framework:

1) Planning for Green as a core part of business strategy: Companies need to plan comprehensively toincrease the use of Green energy, shift the product portfolio to Green products and overhaul business operations towards Green processes. Companies should develop Green indices or scorecards quantifying the impact of the Green initiatives they have undertaken, set specific targets on those indices and track progress against those targets

2) Executing green initiatives across the value chain by shifting towards green energy, green products and green processes or practices

3) Communicating and promoting green initiatives and their benefits to all stakeholders by awareness generation, promotion and product advertisement.

\subsubsection{Execution of framework}

Execution is of vital importance among 3 step Green manufacturing framework and it is desirable to discuss it in detail. With a robust plan in place and targets clearly defined and monitored, Green needs to be integrated across the value chain and made a part of the core business. Execution can be commanded by focussing on Green energy, Green Products and Green Processes.

a) Green Energy: Manufacturing companies with high energy consumption can shift towards using cleaner energy and plan for increasing the efficiency of its use. Setting up captive wind or solar power generation units and using energy efficient practices, such as installing LED lighting or better use of daylight in building design, can go a long way towards reducing the energy intensity of operations. India's efforts to shift to renewable energy and energy efficient practices like Perform-AchieveTrade (PAT) are in concurrence with framework.

b) Green Products: How we make our products is the largest piece of our carbon footprint. We've identified two areas where we can dramatically reduce our impact: raw materials production and electricity used in manufacturing. Moving towards a Green product portfolio, companies should conduct an evaluation of their products based on (a) how Green are the resources and energy being used, (b) how Green is the product during the lifecycle of its use, and (c) how Green is the manufacturing process. By quantifying these parameters, companies can assess the Green value of their product offering. At planning stage itself companies can set these targets and strategies to achieve them.

c) Green Processes: Based on critical success factors companies can gradually evolve its own business processes, technologies as mentioned in figure 8 making manufacturing operations more sustainable.

- Close loop manufacturing process: Manymanufacturers are looking into so-called closedloop manufacturing, wherein products are remanufactured andrepurposed from recovered, possibly already recycled ones. Material saving helps to reduce cost of product and process becomes efficient. But by making this process further efficient one; green technologies can be adopted.

- Green process in supply chain: Green supplychain is new supply chain model which make product delivery more efficient and environmentally competitive. This includes product design, manufacturing processes, delivery of final product and end-of-life management of product after its useful life. Waste reduction, Freight optimization, increase in efficiency, and increase in renewable energy use, environmentally friendly raw materials (for example, no toxic chemicals) are some quick improvements of supply chain initiatives. Retirements of less efficient production facilities and redesigning of network to reduce transportation needs can be termed as examples of fundamental shifts in supply chain towards green manufacturing.

\subsection{Green manufacturing practices}

Green Manufacturing practices are wide ranging and can change from industry to industry. Not only industry profile but type of product to be manufactured, process involved in manufacturing and materials required for making a product will have an impact on adopting green manufacturing practices. But a pattern of green manufacturing can be evolved based on the processes involved in production. Based on that green manufacturing initiatives can be introduced at 3 stages

1) Reducing input for production at first place

2) Improving the efficiency of facility operations

3) Improving products to reduce impact in use and at the end of life

As it is clear that green manufacturing practices changes with change in industry, product and process employed in manufacturing; certain common green practices can be employed in all industries are mentioned below.

1) Simulation of processes before actual production

2) Devising efficient parameters for every tool employed in production

3) Following environmental standards like ISO 14000 family.

4) Sustainable packaging of product and returnable packaging

5) Enhancing industrial energy efficiency by regular energy auditing and implementing recommendations obtained from such reports

6) Promote energy management standards

7) Greening of supply chain by efficient transport. Using vehicles with Biofuels, hybrid vehicles or electric vehicles

8) Just in Time (JIT) and similar approaches to be followed which helps to reduce inventory, improves inventory management thereby reducing costs

9) Partnering with clients for clean energy and clean transport

10) $4 R$ (Reduce, Reuse, Recycle, Remanufacturing) centric product development

11) Setting up sustainability benchmarks to improve manufacturing standards with time. 


\section{International Journal of Science and Research (IJSR) \\ ISSN (Online): 2319-7064 \\ Index Copernicus Value (2015): 78.96 | Impact Factor (2015): 6.391}

\section{Green manufacturing agenda for India}

Governments work to develop environmentally competitive economy is evident from the discussions in above in sections. It has also initiated many new schemes/programs dedicated to manufacturing sector. Setting up emission and discharge standards, Technology acquisition and development fund (TADF) or setting up Green Manufacturing Committee as per National Manufacturing Policy [1] are some dedicated efforts to promote green manufacturing.

Agenda for India includes imperatives for industry as well as for policy makers. Business entities must develop green manufacturing related strategies, and make a clear business case and value proposition for sustainability. Imbibing green perspective in governance, utilization of ICT tools that enables green manufacturing is need of the hour. Like Indian industry policymakers too actively engage in developing green framework of industry. There is a strong need to strengthen policies and coordinate incentives from dedicated agencies and to promote efficiency measures during manufacturing in a key energy and resource intensive industries.

Enhancing technology co-operation internationally and within Indian industries should be key priority to realize the green practices in manufacturing sector. Foreign acquisition, Overseas Research and development houses, global joint ventures are some unconventional transfer mechanism with higher degree of cross border interaction while foreign direct investment, Local joint ventures with MNC and technology licensing are some conventional means of co-operations which should be utilized [28].

\section{Conclusion}

Current situation in India are favorable to growth of manufacturing sector. Recognition to climate change and taking actions to mitigate ill effects of it is a priority for India irrespective of domestic development imperatives. Make In India initiative promoting ambitious industry led development while Indian government also making it concurrent with global climate change efforts. Recognizing COP 21 commitments India also submitted its INDC's which are supporting for sustainable manufacturing practices.

In current paper various perspectives of green manufacturing have been identified. Green manufacturing implementation framework explained in paper certainly provides inputs for industry to shift to green practices. Green processes in business operations are separately discussed. Closed loop manufacturing and green supply chain management initiatives discussed can be foundation to further innovation and implementation of green manufacturing. At last by analyzing case studies and critical success factors for implementation of green manufacturing; common green practices are enlisted which can be implemented in every industry.

Green manufacturing holds potential to meet both manufacturing and environmental challenges but coordinated efforts of both industry and government are required to realize it. To that effect an agenda for India is discussed which will help to shape future discussions in green manufacturing innovation, implementation and sustenance. Many initiatives by government like PAT, CBIPM, and Zero Effects - Zero Defect are taken to make industry more efficient and sustainable. With this a good start has been made to improve manufacturing sector. Upcoming years will be crucial for implementation of announcements, and seizing the opportunity to make the right investment at industry level and making sustainability non-negotiable.

\section{References}

[1] Ministry of commerce and Industry, Departnment of Industrial policy and promotion, Governmenrt of India, "National Manufacturing Policy" [Online].Available:

http://dipp.nic.in/English/policies/National_Manufactu ri

ng_Policy_25October2011.pdf[Accessed:November15 , 2016].

[2] Web portal, Make In India, [Online] Available: http://www.makeinindia.com/home[Accessed:Novem ber 17, 2016].

[3] Intergovernmental panel on climate change, Fifth Assesment Report, [Online] Available:

https://www.ipcc.ch/pdf/assessmentreport/ar5/syr/SYR_AR5_FINAL_full_wcover.pdf [Accessed: November 17, 2016].

[4] Paris Agreement, Page.5, Article 2 (a), [Online] Available

http://unfccc.int/files/essential_background/conventio $\mathrm{n} /$

application/pdf/english_paris_agreement.pdf[Accesse d: November 17, 2016]

[5] Sustainable development goals, sustainabledevelopment.un.org, [Online] Available: https://sustainabledevelopment.un.org/topics/sustainab le developmentgoals[Acceseed:December 2, 2016]

[6] India's INDC, moef.gov.in, [Online]Available: http://www.moef.gov.in/sites/default/files/INDIA\%20 I NDC\%20TO\%20UNFCCC.pdf[Accessed:

November20-28, 2016]

[7] Minhaj Ahemad.A Rehman.et.al, "Validating Green manufacturing (GM) Framework for Sustainable Development in Indian Steel Industry", Universal Journal Of mechanical Engineering 1(2): pp. 49-61, 2013

[8] Srijan Manish and Danduram Soren, "Green Manufacturing and its impact on Environmental Sustainability", Energy and Environment Sustainability, B.I.T Sindri, pp. 124-127, 2013

[9] Michael E Porter and Claas van der Linde, "Green and Competetive : Ending the stalemate", Harvard Business Review, September-October 1995 issue [Online], Available: https://hbr.org/1995/09/greenand-competitive-ending-thestalemate[Accessed:December12, 2016]

[10] Sam Fankhauser et.al, "Who will win the green race? In search of environmental competitiveness and innovation", Global environment challenge, (23), pp. 


\section{International Journal of Science and Research (IJSR) \\ ISSN (Online): 2319-7064 \\ Index Copernicus Value (2015): 78.96 | Impact Factor (2015): 6.391}

902-913, 2013

[11] United nations Environment Programme, Climate Change mitigation, www,unep.org, [Online], Available:http://www.unep.org/climatechange/mitigati on/Manufacturing/tabid/104340/Default.aspx[Accesse d:December 11, 2016]

[12] Arindam Bhattacharya et.al, "Make In India: Turning Vision into Reality", CII $13^{\text {th }}$ Manufacturing Summit Report, 2014

[13] India GDP from manufacturing, Forecast 2016-2020, www.tradingeconomics.com,[Online], Available: http://www.tradingeconomics.com/india/gdp-frommanufacturing/forecast[Accessed:December 15, 2016]

[14] Arun Bruce et.al, "Future of Indian Manufacturing: Bridging the Gap", CII $14^{\text {th }}$ Manufacturing summit Report, 2015

[15] International Energy Agency, "India Energy Outlook", World Energy Outlook Special Report, pp. 25, 2015

[16] India's Intended Nationally Determined ContributionsTowards Climate Justice, www.moef.gov.in,[Online], Available:

http://www.moef.gov.in/sites/default/files/pressreleases/revised\%20PPT\%20Press\%20Conference\%2 0I NDC\%20v5.pdf,[Accessed :November 29, 2016]

[17] United nations framework convention on climate change, GHG Emission profiles for Non-Annex-1 parties, [Online], Available: http://di.unfccc.int/NonAnnex.aspx[Accessed:Novemb er 29, 2016]

[18] United nations framework convention on climate change, GHG inventories data-Detailed data by party, [Online], Available:

http://di.unfccc.int/DetailedDataByParty.aspx

[Accessed: November 29, 2016]

[19] Minhaj Ahemad Rehman et.al, "Impact of green manufacturing practices on organisational performance in Indian Context: An empirical study", Journal of Cleaner Production, Volume 137, pp. $427-$ 448, 2016

[20] Perez, C., "Technological revolutions and technoeconomic paradigms". Cambridge Journal of Economics 34, pp.185-202, 2010

[21] Stern, N., "China's Growth, China's Cities and the New Global Low-Carbon Industrial Revolution." Policy Brief. Grantham Research Institute, London School of Economics November., 2010

[22] Organisation for Economic co-operation and development, Green growth and sustainable development, [Online], Available: http://www.oecd.org/greengrowth/whatisgreengrowtha n dhowcanithelpdeliversustainabledevelopment.htm ,[Accessed: November 26, 2016]

[23] Organisation for Economic co-operation and development, "Green growth and developing countries: A summary for policy makers”, 2012

[24] Rahul Jain, Vivek Bhatia, "Green Manufacturing: Imperatives for Indian Industry", The Boston Consultancy Group, 2013

[25] Arindam Bhattacharya, Rahul Jain, Amar Chaudhari, "Green Manufacturing: Energy, product and Processes", The Boston Consultancy group, Confederation of Indian Industry, March 2011

[26] E. Somanathan et.al, "The Impact of Temperature on
Productivity and Labor Supply: Evidence from Indian Manufacturing" Discussion papers in economics, Indian Statistical Institute, Delhi, 2014

[27] Pujari.D Wright G. And Peattie K, "Green \& competitive influence on environmental new product development performance", Journal of business research, Vol 56 issue 8 ,pp 657-671., 2003

[28] Fei Ding et.al, "Green energy development and technology transfer in China and India”, Journal of International development and cooperation, Vol.19, No.2, pp.13-24, 2012

\section{Author Profile}

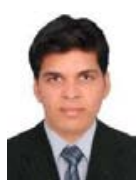

Nikhil Sudhir Kothawade received the B.E.(2013) fromAmrutvahini College of Engineering, Sangamner in Mechanical Engineering. He has completed his M.Tech (2015) in Manufacturing Sciences from VIT University, Vellore. He has worked with Severn Glocon Pvt Ltd, Chennai on production improvement projects. His area of interest includes advance manufacturing methods, metal matrix composites, Green Manufacturing and Production planning \& Control.

\section{Volume 6 Issue 1, January 2017 www.ijsr.net}

